\title{
Correction to: Appraisal Accuracy and Automated Valuation Models in Rural Areas
}

\author{
Alexander N. Bogin ${ }^{1} \cdot$ Jessica Shui ${ }^{1}$ \\ Published online: 13 November 2019 \\ (C) This is a U.S. Government work and not under copyright protection in the US; foreign copyright protection may \\ apply 2019
}

\section{Correction to: J Real Estate Finan Econ (2019) https://doi.org/10.1007/s11146-019-09712-0}

The article Appraisal Accuracy and Automated Valuation Models in Rural Areas, written by Alexander N. Bogin and Jessica Shui, was originally published electronically on the publisher's internet portal (currently SpringerLink) on August 2019 without open access.

With the author(s)' decision to opt for Open Choice the copyright of the article changed on September 2019 to (C) This is a U.S. government work and not under copyright protection in the U.S.; foreign copyright protection may apply 2019 and the article is forthwith distributed under the terms of the Creative Commons Attribution 4.0 International License (http://creativecommons. org/licenses/by/4.0/), which permits use, duplication, adaptation, distribution and reproduction in any medium or format, as long as you give appropriate credit to the original author(s) and the source, provide a link to the Creative Commons license and indicate if changes were made.

The original article has been corrected.

The online version of the original article can be found at https://doi.org/10.1007/s11146-019-09712-0

Jessica Shui

jessica.shui@fhfa.gov

Alexander N. Bogin

alexander.bogin@fhfa.gov

1 Federal Housing Finance Agency, Office of Policy Analysis \& Research, 400 7th Street SW, Washington, DC 20219, USA 
Open Access This article is distributed under the terms of the Creative Commons Attribution 4.0 International License (http://creativecommons.org/licenses/by/4.0/), which permits unrestricted use, distribution, and reproduction in any medium, provided you give appropriate credit to the original author(s) and the source, provide a link to the Creative Commons license, and indicate if changes were made.

Publisher's Note Springer Nature remains neutral with regard to jurisdictional claims in published maps and institutional affiliations. 